\title{
Penyelesaian Tindak Pidana Perzinahan dalam Hukum Adat di Kabupaten Batanghari
}

\author{
Islah \\ Fakultas Hukum, Universitas Batanghari \\ Jln. Walisongo Lrg. Sidodadi RT. 03 Kel. Kenali Besar, Kec. Alam Barajo, JambTelp: 081274741183 \\ Correspondence email islah@unbari.ac.id
}

\begin{abstract}
Abstrak. Hukum pidana adat atau hukum pelanggaran adat ialah aturan-aturan hukum adat yang mengatur peristiwa atau perbuatan kesalahan yang berakibat terganggunya keseimbangan masyarakat sehingga perlu di selesaikan (di hukum) agar keseimbangan masyarakat tidak terganggu. Salah satu wilayah yang masih menerapkan Hukum Adat sebagai aturan yang ditaati.Dalam kehidupan bermasyarakat, hukum dan masyarakat merupakan dua hal yang yang tidak dapat dipisahkan. Oleh karena itu dibutuhkan suatu aturan hukum untuk mengatur kehidupan bermasyarakat demi mencapai ketertiban umum. Aturan hukum tersebut ada yang tertulis maupun yang tidak tertulis. Berlaku secara nasional maupun kedaerahan, di dalam lapangan hukum publik maupun hukum privat. Pelanggaran adat ialah aturan-aturan hukum adat yang mengatur peristiwa atau perbuatan kesalahan yang berakibat terganggunya keseimbangan masyarakat sehingga perlu di selesaikan (di hukum) agar keseimbangan masyarakat tidak terganggu. Salah satu wilayah yang masih menerapkan Hukum Adat sebagai aturan yang ditaati oleh masyarakat seperti yang terjadi di Kabupaten Batanghari masyarakat masih menghormati hukum adat dalam penyelesaian kasus-kasus seperti tindak pidana perzinahan
\end{abstract}

Kata Kunci: Penyelesaian Tindak Pidana Perzinahan

\begin{abstract}
Customary criminal law or customary violation law are customary law rules that regulate events or wrongdoing that result in disturbing the balance of the community so that it needs to be resolved (in law) so that the balance of the community is not disturbed. One of the areas that still applies customary law as a rule that is obeyed. In social life, law and society are two things that cannot be separated. Therefore we need a rule of law to regulate social life in order to achieve public order. These legal rules are either written or unwritten. Applicable nationally and regionally, in the field of public law and private law. Customary violations are rules of customary law that regulate events or wrongdoing that result in disturbing the balance of the community so that it needs to be resolved (in law) so that the balance of the community is not disturbed. One of the areas that still applies Customary Law as a rule that is obeyed by the community, as happened in Batanghari Regency, the community still respects customary law in solving cases such as the crime of adultery
\end{abstract}

Keywords: Settlement of the Crime of Adultery

\section{PENDAHULUAN}

Didalam lapangan hukum pidana, ada dua hukum berbeda yang digunakan oleh masyarakat yaitu hukum pidana yang bersumber kepada peraturan tidak tertulis dan hukum pidana yang bersumber pada KUHP serta peraturan yang tertulis ataupun kebiasaan yaitu hukum pidana adat. Hukum pidana adat atau hukum pelanggaran adat ialah aturanaturan hukum adat yang mengatur peristiwa atau perbuatan kesalahan yang berakibat terganggunya keseimbangan masyarakat sehingga perlu di selesaikan (di hukum) agar keseimbangan masyarakat tidak terganggu. Salah satu wilayah yang masih menerapkan Hukum Adat sebagai aturan yang ditaati.

Hukum adat adalah hukum Indonesia asli yang tidak tertulis dalam bentuk perundang-undangan Republik Indonesia, yang mengandung unsur agama.1Dari kesimpulan tersebut dapat pula dikatakan bahwa Hukum Pidana Adat adalah hukum Indonesia asli yang tidak tertulis dalam bentuk perundang-undangan yang mengandung unsur agama, diikuti dan ditaati oleh masyarakat secara terus-menerus, dari satu generasike generasi selanjutnya. Indonesia merupakan bangsa yang masyarakatnya memiliki keragaman suku, ras, agama dan adat kebiasaan yang tersebar di kota dan di desa. Keragaman itu menjadi suatu kekayaan dan potensi yang dimiliki oleh bangsa Indonesia. Dalam kehidupan bermasyarakat, hukum dan masyarakat merupakan dua hal yang yang tidak dapat dipisahkan. Antara hukum dengan kehidupan masyarakat memang berkaitan erat, hukum berperan besar dalam mewujudkan kehidupan yang tertib dan aman. Apabila terjadi hal-hal yang menyimpang maka peran hukum dapat dilihat secara lebih konkrit. Di dalam lapangan hukum pidana, ada dua hukum yang berbeda yang digunakan oleh masyarakat yaitu hukum pidana yang bersumber pada peraturan tidak tertulis lainya dan hukum yang bersumber pada KUHP serta peraturan yang tertulis ataupun kebiasaan yaitu Hukum pidana adat. ${ }^{1}$

${ }^{1}$ Topo SAntoso. Pluralisme Hukum Pidana Indonesia. Jakarta: PT.Ersesco, 1990 hal 5-6 
Keberadaan Hukum Pidana Adat pada masyarakat merupakan pencerminan kehidupan masyarakat tersebut dan pada masing-masing daerah memiliki Hukum Pidana Adat yang berbeda sesuai dengan adat istiadat yang ada di daerah tersebut dengan ciri khas tidak tertulis ataupun terkodifikasikan. ${ }^{2}$

Di dalam kehidupan atau pergaulan masyarakat banyak perbuatan-perbuatan yang dapat digolongkan dalam perbuatan yang melanggar hukum adat maupun hukum Negara, diantaranya adalah perzinahan, Perzinahan merupakan perbuatan yang dapat digolongkan sebagai kejahatan terhadap kesusilaan. Perbuatan ini tidak hanya melanggar ketentuan hukum pidana tetapi, melainkan juga melanggar norma-norma yang tidak tertulis (hak adat) yangberlaku di lingkungan masyarakat tertentu, erhadap perbuatan zina itu masing-masing masyarakat adat akan mempunyai aturan yang berbeda satu sama lain, menurut hukum adat persetubuhan antara pria dan wanita diluar ikatan perkawinan yang sah adalah perbuatan zina. ${ }^{3}$

Dalam Kitab undang-undang Hukum Pidana (KUHP) perbuatan zina diatur dalam pasal 284 yaitu persetubuhan yang dilakukan oleh pria dan wanita yang masing-masing atau salah satu pihak masih terikat oleh perkawinan yang sah dengan pihak lain. ${ }^{4}$

Pengertian Adat Jambi dalam pandangan kehidupan masyarakat adat dan umum di Jambi memiliki ,adat dalam arti budaya yaitu kebiasaan yang dilakukan turun menurun yang berlaku ditengah masyarakat, yang mana bila dikerjakan atau tidak dikerjakan tidak terdapat sanksi. Misalnya menghiasi kamar, memakan sirih dan lain sebaginya.Adat dalam artian etika yaitu perilaku atau tingkah laku seseorang yang mana apabila kebiasaan itu sesuai dengan etika dikatakan baik namun bila tidak sesuai dikatakan tidak baik misalnya makan tidak berdiri, shalat jum' at menggunakan sarung dan lain sebagainya. Tidak terdapat sanksi pada tataran ini apabila tidak merugikan orang lain.Adat dalam artian hukum yaitu kebiasaan yang dilarang dalam hukum adat atau diperintahkan oleh hukum adat jika ada seseorang melanggarnya maka akan menerima sanksi adat. Misalnya mencuri, membunuh, berzina, mengambil hak saudaranya dan lain sebagainya yang diatur oleh adat kebiasaan atau pun tidak diatur namun merugikan orang lain.

Hukum adat keseluruhan aturan tingkah laku positif yang di satu pihak mempunyai sanksi dan pihak lain dalam keadaan tidak dikodifikasikan dengan kata lain hukum adat adalah adat kebiasaan yang mempunyai akibat hukum. Sistem hukum adat bersumber kepada peraturan-peraturan yang tidak tertulis yang tumbuh dan berkembang dan dipertahankan dengan kesadaran hukum masyarakatnya, dan hukum adat itu mempunyai tipe tradisional dengan berpangkal pada kehendak nenek moyang, artinya untuk ketertiban hukumnya selalu diberikan penghormatan yang sangat besar bagi kehendak suci nenek moyang itu. ${ }^{5}$ Hubungan antara hukum dan kehidupan masyarakat memang berkaitan erat, hukum berperan besar dalam mewujudkan kehidupan yang tertib dan aman. Apabila terjadi hal-hal yang menyimpang maka peran hukum adat dapat dilihat secara lebih konkrit.

Hukum pidana adat atau hukum pelanggaran adat ialah aturan-aturan hukum adat yang mengatur peristiwa atau perbuatan kesalahan yang berakibat terganggunya keseimbangan masyarakat sehingga perlu di selesaikan (di hukum) agar keseimbangan masyarakat tidak terganggu. Salah satu wilayah yang masih menerapkan Hukum Adat sebagai aturan yang ditaati.Dalam kehidupan bermasyarakat, hukum dan masyarakat merupakan dua hal yang yang tidak dapat dipisahkan. Oleh karena itu dibutuhkan suatu aturan hukum untuk mengatur kehidupan bermasyarakat demi mencapai ketertiban umum. Aturan hukum tersebut ada yang tertulis maupun yang tidak tertulis. Berlaku secara nasional maupun kedaerahan, di dalam lapangan hukum publik maupun hukum privat. ${ }^{6}$

Pelanggaran adat ialah aturan-aturan hukum adat yang mengatur peristiwa atau perbuatan kesalahan yang berakibat terganggunya keseimbangan masyarakat sehingga perlu di selesaikan (di hukum) agar keseimbangan masyarakat tidak terganggu. Salah satu wilayah yang masih menerapkan Hukum Adat sebagai aturan yang ditaati oleh masyarakat seperti yang terjadi di Kabupaten Batanghari masyarakat masih menghormati hukum adat dalam penyelesaian kasus-kasus seperti tindak pidana perzinahan.

Dalam Kitab Undang-Undang Hukum Pidana (KUHP) yang berlaku saat ini, delik zina sudah diatur dan masuk dalam rumusan delik. Adapun, ketentuan mengenai zina diatur dalam Pasal 284 KUHP, dapat dirumuskan sebagai berikut:

Diancam dengan pidana penjara paling lama Sembilan bulan:

1. Seorang pria yang turut serta melakukan perbuatan itu, padahal diketahuinya bahwa yang turut bersalah telah kawin;

2. Seorang wanita yang telah kawin yang turut serta melakukan perbuatan itu, padahal diketahui olehnya bahwa yang turut bersalah telah kawin dan Pasal 27 KUH Perdata berlaku baginya.

\footnotetext{
${ }^{2}$ Chairul Anwar. Hukum Adat Indonesia Meninjau Hukum Adat Minangkabau. Jakarta:Rineka Cipta,1997 hal 11

${ }^{3}$ Ter Haaar, Pengantar Hukum Adat, Bandung1 998, hal. 3

${ }^{4}$ Moeljatno, Kitab Undang-Undang Hukum Pidana, Bandung Alumni, 1998, hal. 104

5 Titik Triwulan Tutik, Pengantar Ilmu Hukum, Prestasi Pustakaraya, Jakarta, 2006, hal 100

${ }^{6}$.Tolip Setiady, Intisari Hukum Adat indonesi, Alfabeta, Bandung, 2009, hal. 134.
} 
Di dalam masyarakat Provinsi Jambi secara mayoritas adalah pemeluk agama Islam, akan tetapi tidak semua hukum syari'at agama Islam itu langsung serta merta saja diambil serta dipraktekkan dalam kehiduapan masyarakat Provinsi Jambi, akan tetapi hal itu perlu dipertimbangkan terlebih dahulu secara matang sebelum diadakannya untuk menetapkan sebuah hukuman yang ada, karena banyak sekali aspek-aspek yang harus dilihat dan dipertimbangkan terlebih dahulu sebelum menetapkan hukuman sebagai aturan yang diterapkan di masyarakat terhadap persoalan terlebih lagi terhadap hukum dera (jilid), pengasingan (taghrib) bagi pelaku zina, terutama dalam hal penetapan sanksi bagi pelaku zina, baik itu zina yang dilakukan bagi orang yang telah menikah (berkeluarga) maupun zina yang dilakukan bagi orang yang belum pernah menikah (jejaka dan perawan), dalam hal ini secara umum masyarakat adat yang ada di Provinsi Jambi ternyata lebih cenderung kepada hukum adat yang sudah menjadi adat istiadat yang ada secara turun temurun dari sejak zaman nenek moyang terdahulu sampai pada masa sekarang yang sudah menjadi budaya bagi masyarakat Provinsi Jambi, berdasarkan pada informasi yang diperoleh peneliti yang didapatkan dari lapanganSecara historis hukum adat melayu Jambi tidak dapat dipisahkan dengan masa kejayaan hindu dan Islam atau dengan bahasa lain kontestasi agama dan madzhab dalam yang mempengaruhi lahirnya hukum adat melayu Jambi. Menurut Lemabaga Adat Melayu Jambi (LAM) Keberagamaan adat dan budaya dalam masyarakat di Jambi merupakan hukum adat yang tak terelakan. Khususnya dalam masyarakat Provinsi jambi yang memiliki keunikan lokal yang terbilang salah satu suku melayu tertua. Salah satunya adalah Lembaga Adat Melayu Jambi yang berdiri kokoh jauh sebelum Kemerdekaan.

Di masa pemberlakuan otonomi daerah saat ini, dimana setiap daerah diberi kewenangan menyelenggarakan pemerintahannya sendiri dan harus berdasarkan pada prinsip -prinsip antara lain otonomi yang bertanggung jawab menekankan pada demokrasi, menunjang aspirasi, peran serta masyarakat dan potensi daerah maupun keanekaragaman daerah. Tiap daerah tersebut memiliki kemampuan ekonomi, jumlah penduduk, luas daerah, sosial budaya yang berbeda-beda sehingga tidak menutup kemungkinan dalam menyelesaikan masalahnya menggunakan cara yang berbeda pula, termasuk dalam lapangan hukum publik karena didasari oleh latar belakang yang berbeda pula. ${ }^{7}$ Sanksi tersebut merupakan kesepakatan yang telah di tetapkan oleh pemuka-pemuka adat ${ }^{8}$. Salah satu wilayah yang masih menerapkan Hukum Adat sebagai aturan yang ditaatioleh masyarakat adalah hukum Adat di Kabupaten Batanghari.

Terjadinya perbuatan zina dikarenakan faktor Cinta, Mau sama mau, Pemenuhan tuntutan biologis, Mencari kepuasan, Ekonomi, Paksaan atau kurangnya iman. Peranan Hukum Adat dalam Penyelesaian perkara perbuatan zina Di Kabupaten Batanghari sebagian besar diselesaikan melalui penyelesaian secara adat di kantor Balai Desa, balai adat atau di rumah kepala desa yang penyelesaian melalui berapatan tenganai nenek mamak atau kabupaten kelurahan. Dilakukan penyelesaian tidak perzinahan melalui cara-cara damai dan kekeluargaan dipegaruhi oleh faktor-faktor penegakan hukum seperti faktor hukum, faktor tersebut, faktor masyarakatlah yang paling berperan, dimana masyarakat sedirilah yang enggan menyelesaikan perkaranya melalui peradilan sehingga memilih upaya damai kekeluargaan.

Berzina menurut lembaga adat yang mengatakan bahwa dalam hukum agama islam merupakan sebuah dosa besar. Pezina yang sudah memiliki pasangan sah atau sudah menikah (berselingkuh) disebut Pezinah Muhshan. Perbuatan zina diharamkan, termasuk dosa besar berdasarkan dalil-dalil berikut ini" Dan janganlah kamu mendekati zina, sesungguhnya zina itu adalah suatu perbuatan yang keji.

Setiap hukum merupakan suatu sistem, peraturan-peraturannya merupakan suatu kebulatan berdasarkan kesatuan alam pikiran masyarakatnya. Begitupun hukum adat, sistem hukum adat bersendi atas dasar-dasar alam pikiran bangsa Indonesia, yang tidak sama dengan alam pikiran yang menguasai sistem hukum barat. ${ }^{9}$ Hukum Adat mengandung sifat yang tradisional, berpangkal pada kehendak nenek moyang.

\section{METODE}

Penelitian ini merupakan penelitian hukum empiris yaitu suatu penelitian hukum yang bertipe terfokus pada fakta -fakta di lapangan terdapat dengan tipe penelitian ini,maka pendekatan Socio Kriminologis.

Dilihat dari tujuan penelitian ini maka penelitian yang dilakukan bersifat diskriptif analitis, yaitu memaparkan, menggambarkan atau mengungkapkan penerapan dilapangan dan hasil yang didapatkan dalam penelitian ini akan dianalisis menggunakan teori yang relevan dan menyimpulkannya.

\section{Metode Pendekatan}

Pendekatan penelitian yang penulis gunakan pada penelitian ini yaitu menggunakan pendekatan yuridis empiris yaitu suatu penelitian hukum yang bertipe terfokus pada fakta -fakta di lapangan terdapat dengan tipe penelitian ini,

\footnotetext{
${ }^{7}$ Ibid, hal 11

${ }^{8}$ Tolip Setiady, Intisari Hukum Adat indonesia, Alfabeta, Bandung, 2009, hal. 134.

${ }^{9}$ Soepomo, Bab-bab tentang Hukum Adat, Penerbit Universitas, Jakarta, 1966, hal 25
} 
maka pendekatan Socio Kriminologis.semua informasi dengan pengamatan dan wawancara langsung terhadap objek penelitian. ${ }^{10}$

\section{Rancangan kegiatan}

Dalam penelitian ini yaitu penelitian hukum deskriptif analitis dilakukan rancangan kegiatan guna memeprmudah dan mempercepat penelitian ini dilakukan serta dalam pelaksanaan penelitian ini akan tersistematis khususnya mengenai Penyelesaian Tindak Pidana Perzinahan Dalam Hukum Adat Di Kabupaten Batanghari.

Untuk itu, apabila dilihat dalam penelitian ini yang mana menggunakan pendekatan yuridis normative, maka rancangan kegiatan yang dilakukan di dalam penelitian ini adalah langsung menganalisis Penyelesaian Tindak Pidana Perzinahan Dalam Hukum Adat Di Kabupaten Batanghari.

\section{Ruang lingkup atau objek}

Dalam suatu penelitian diperlukan objek atau sasaran penelitian dan adanya batasan atau ruang lingkup penelitian agar penelitian yang dilakukan lebih terarah dan tidak meluas. Adapaun ruang lingkup atau objek dari penelitian ini yaitu Penyelesaian Tindak Pidana Perzinahan Dalam Hukum Adat Di Kabupaten Batanghari

\section{Bahan dan alat utama}

Bahan dan alat utama dalam penelitian ini karena penelitian ini bersifat hukum normatif, maka sumber data penelitian ini menggunakan sumber data kepustakaan yaitu:

1. Bahan Hukum Primer atau bahan hukum yang memiliki sifat infiris, artinya mempunyai otoritas. Bahan-bahan hukum primer terdiri dari perundang-undangan, yaitu : Undang-Undang Hukum Pidana (KUHP ) Adapun, ketentuan mengenai zina diatur dalam Pasal 284 KUHP

2. Bahan Hukum sekunder yang berupa buku-buku atau literatur-literatur yang berkaitan dengan penelitian ini.

3. Bahan Hukum Tertier yaitu KBBI dan Kamus Hukum

\section{Teknik pengumpulan data}

Teknik pengumpulan data pada penelitian ini menggunakan metode wawancara, metode studi pustaka atau studi dokumen dan juga menggunakan metode observasi. Metode tersebut digunakan untuk mendapatkan data yang bisa digunakan dalam memecahkan permasalahan yang diteliti yaitu mengenai Penyelesaian Tindak Pidana Perzinahan Dalam Hukum Adat Di Kabupaten Batanghari.

\section{Teknik analisis}

Setelah semua data dikumpulkan maka untuk selanjutnya data tersebut dianalisis secara kualitatif yaitu menganalisa data berdasarkan keterangan atau jawaban responden dan ditarik kesimpulan bersifat deskriptif, mengenai masalah yang dibahas.

\section{HASIL DAN PEMBAHASAN \\ Penyelesaian Tindak Pidana Perzinahan Dalam Hukum Adat Di Kabupaten Batanghari}

Hukum pidana adat adalah hukum yang hidup mengatur tindakan yang melanggar perasaan keadilan dan kepatutan yang hidup ditengah masyarakat, sehingga menyebabkan terganggunya ketentraman serta keseimbangan masyarakat. Untuk memulihkan ketenteraman dan keseimbangan tersebut, maka terjadi reaksi adat. Dalam mempertahankan hukum pidana adat, dimana setiap permasalahan dapat diselesaikan secara tuntas, terhadap setiap permasalahan yang ada dan yang mungkin ada, karena hukum pidana adat lebih mengutamakan tercapainya tujuan, yaitu kebersamaan daripada memegang teguh suatu ketentuan yang telah ditentukan oleh Negara.

Kabupaten Batanghari penyelesaian kasus-kasus perzinahan lebih banayak diselesaikan secara hukum pidana adat, masyarakat tidak ingin membawah kerana hukum pidana, dikarena hukum sanksi adat dianggap tidak terlalu memberatkan dibandingkan hukum pidana.

Penyelesaian perkara di luar pengadilan melalui mediasi merupakan perkembangan baru dalam ranah hukum pidana yang membawa implikasi mulai diterapkan dimensi bersifat privat ke dalam ranah hukum publik. Pada hukum positif indonesia asasnya perkara pidana tidak dapat diselesaikan di luar pengadilan, walaupun dalam hal-hal tertentu dimungkinkan adanya penyelesaian kasus di luar pengadilan. Akan tetapi, praktik penegakan hukum di Indonesia sering juga perkara pidana diselesaikan diluar pengadilan melalui diskresi aparat penegak hukum, mekanisme perdamaian, lembaga adat dan lain sebagainya

Tindak pidana zina merupakan kejahatan yang menyangkut kehormatan seseorang yang seharusnya dihukum berat namun dalam Kitab Undang-Undang Hukum Pidana hanya diancamkan hukuman maksimal 9 (sembilan) bulan

\footnotetext{
${ }^{10}$ Ronny Hanitijo Soemitro, Metode Penelitian Hukum dan Jurimetri, Jakarta, Ghalia Indonesia, 1988, hal. 11.
} 
penjara dan harus memenuhi beberapa syarat, sebagaimana dijelaskan dalam Pasal 284 Kitab Undang-Undang Hukum Pidana (KUHP), bahwa seorang laki-laki atau perempuan dikatakan melakukan kejahatan zina, yaitu:

1. Melakukan persetubuhan dengan perempuan atau laki-laki bukan suami atau isterinya;

2. Bagi dirinya berlaku Pasal 27 Burgerlijk Wetboek Voor Indonesia(BW);

3. Dirinya sedang berada dalam perkawinan.

Berdasarkan Pasal 284 ayat (1) Kitab Undang-undang Hukum Pidana (KUHP), seseorang tidak bisa dikenakan tindak pidanaperzinaan bila dilakukan oleh seorang laki-laki lajang dengan perempuan yang juga lajang. KUHP hanya mendefinisikan zina adalah perbuatan persetubuhan yang dilakukan oleh laki-laki atau perempuan yang telah kawin dengan perempuan atau laki-laki yang bukan istri atau suaminya

Seperti contoh kasus di Kabupaten Batanghari,seorang kades ketahuan selingkuh dengan seorang wanita yang sudah bersuami. Mengetahui hal tersebut sempat menghebohkan warga setempat, yang sangat menyayangkan kejadian ini. Betapa tidak, Kades yang seharusnya menjadi panutan bagi warganya, malah berbuat hal yang tak senonoh.

Setelah diselidiki, dan dengan bukti yang cukup lembaga adat desa setempat serta tokoh masyarakat dalam kasus ini langsusng meperoses dan menyelesaiakan kasus ini secara hukum adat.

Penyelesaian menurut hukum adat yang ada di kabupaten batanghari berasaskan nilai-nilai kebersamaan, yang mengutamakan keselarasan dan keseimbangan dalam kehidupan. Dalam menyelesaikan suatu perkara adat (Tindak Pidana Adat) diperlukan suatu mekanisme penyelesaian yang berdasarkan kebersamaan yaitu musyawarah dan mufakat.

Oleh karena itu pola penyelesaian yang diterapkan harus mengacu pada nilai-nilai keadilan, nilai kepastian hukum dan kemanfaatan. Rasa keadilan terkadang hidup diluar undang-undang, yang jelas undang-undang akan sangat sulit untuk mengimbanginya. Begitupula sebaliknya undang-undang itu sendiri dirasakan tidak adil ketika rasa keadilan itu benar-benar dirasakan oleh mayoritas kolektif maka kepastian hukum akan bergerak menuju rasa keadilan itu sendiri. Kepastian hukum adalah rasa keadilan itu sendiri, sebab keadilan dan hukum bukanlah dua elemen yang terpisah.

"Bagi masyarakat atau orang yang melakukan zina mendapatkan hukuman tersendiri, sesuai dengan perbuatannya, apabila yang melakukan zina itu adalah orang yang telah menikah, maka mereka dihukum dengan membayar denda/hutang kepada masyarakat di kabupaten batanghari dengan membayar denda adat berupa cuci kampung serta membayar selemak semanis.. Menurut tetuo adat dan masyarakat orang berzina dikenakan hukuman denda tersebut adalah bertujuan untuk cuci kampung dan membuat epek jera terhadap para pelaku agar supaya perbuatan tersebut tidak terulang kembali". "Keputusan sidang adat memutuskan denda cuci kampung seekor kerbau beserta asam garam, selemak semanis dihitung seberapa besar kesalahan yang telah dilakukan. Karena perbuatan mereka dianggap mengotori kampung,"

Demikian kata ketua Lembaga Adat Melayu Jambi kabupaten batanhari. Setelah putusan ditetapkan, pihak (LAM) Lembaga Adat Melayu tinggal menunggu realisasi kepatuhan daripada pihak lelaki untuk menyelesaikan hutang adatyang dibebankan kepadanya. Keduanya, baik laki-laki dan perempuannya mengakui telah melakukan hubungan suami istri secara tidak sah itu. Pengakuannya atas dasar suka sama suka. Hubungan itu sudah melanggar tatanan kehidupan masyarakat dan adat istiadat,seta agama islam,Keduanya memang masih terikat janji perkawinan masing-masing dengan pasangan sahnya.

Kebanyakan masyarakat di kabupaten batangahri ,hanya mengetahui proses penyelesaian pekara tindak pidana khususnya tindak pidan zina hanya sampai pada tingkat lembaga adat atau ditingkat pemangku adat yang ada didaerah tersebut, dikarenakan kebanyakan kasus perkara tindak pidana khususnya tindak pidana zina sudah selesai pada tingkat ini Dalam kasus perzinahan ini yang biasa ditangani oleh adat ini biasanya menangani perkara zina antara lakilaki dan perempuan yang memiliki dan yang kedua seorang istri yang melakukan zina dengan seorang laki-laki lain yang mana ia masih terikat perkawinan menurut ketentuan yang berlaku.

Sanksi di dalam hukum pidana adat merupa-kan suatu pemenuhan kewajiban adat yang dijatuhkan oleh kepala adat terhadap orang yang telah melanggar hukum adat. Segala tindakan yang bertentangan dengan peraturan didalam system hokum adat adalah tindakan yang melanggar hukum atau ilegal. Jika terjadi suatu pelanggaran hukum, maka petugas hukum dalam hal ini adalah kepala adat mengambil tindakan konkrit, yakni reak-si adat guna membetulkan hukum yang dil-anggar tersebut.

\section{SIMPULAN}

Penyelesaian yang diterapkan harus mengacu pada nilai-nilai keadilan, nilai kepastian hukum dan kemanfaatan. Rasa keadilan terkadang hidup diluar undang-undang, yang jelas undang-undang akan sangat sulit untuk mengimbanginya. Begitupula sebaliknya undang-undang itu sendiri dirasakan tidak adil ketika rasa keadilan itu benarbenar dirasakan oleh mayoritas kolektif maka kepastian hukum akan bergerak menuju rasa keadilan itu sendiri. Kepastian hukum adalah rasa keadilan itu sendiri, sebab keadilan dan hukum bukanlah dua elemen yang terpisah. 


\section{Saran}

Pemerintah atau lembaga-lembaga yang berwenang dan terkait harus lebih aktif agar dapat berperan untuk melakukan keliling kampong. Dan Kepada masyarakt di kabupaten batanghari diharapkan mematuhi budaya dan adat istiadat yang berlaku di desa tersebut.

\section{DAFTAR PUSTAKA}

Chairul Anwar. Hukum Adat Indonesia Meninjau Hukum Adat Minangkabau. Jakarta:Rineka Cipta,1997 Moeljatno, Kitab Undang-Undang Hukum Pidana, Bandung Alumni, 1998

Ronny Hanitijo Soemitro, Metode Penelitian Hukum dan Jurimetri, Jakarta, Ghalia Indonesia, 1988, Soepomo, Bab-bab tentang Hukum Adat, Penerbit Universitas, Jakarta, 1966,

Titik Triwulan Tutik, Pengantar Ilmu Hukum, Prestasi Pustakaraya, Jakarta, 2006, Tolip Setiady, Intisari Hukum Adat indonesia, Alfabeta, Bandung, 2009,

Topo SAntoso. Pluralisme Hukum Pidana Indonesia. Jakarta: PT.Ersesco, 1990

\section{Peraturan Perundang-undangan}

KUHP Pasal 284 Mengenai Zina 